\title{
Clay mineralogy of landslide occurrences in hydrothermally altered area: A case study of Durensari Area, Purworejo, Central Java
}

\author{
Ilham Dharmawan Putra ${ }^{1}$, Anastasia Dewi Titisari, ${ }^{1, *}$, and Hitznaiti Zaidini Khul Husna ${ }^{1}$ \\ ${ }^{1}$ Department of Geological Engineering, Faculty of Engineering, Universitas Gadjah Mada, Indonesia
}

\begin{abstract}
Landslide is one of the geological phenomena that can be found frequently in Indonesia, where several areas are damaged due to landslide occurrence. One of it is located in Durensari Area, Bagelen, Purworejo, Central Java as the study area. The study area is characterized by the presence of altered volcanic rocks formed by the tertiary eruption, followed by hydrothermal alteration that contains clay minerals that could enhance the landslide occurrence. This study is conducted to identify hydrothermal clay minerals that which enhanced the landslide in the study area. Field mapping is done as field observation, as well as the clay minerals are identified from 10 samples using X-Ray Diffraction (XRD) as the study method. The observation has resulted that there are at least \pm 25 landslide occurrence points in the study area, which is associated with alteration type that consists of several clays, named by smectite, kaolinite, and illite assemblages as argillic alteration and chlorite, smectite, illite, and kaolinite assemblages as propylitic alteration. The research concluded that the replacement process of primary minerals by clay minerals and the presence of smectite affect the landslide occurrence in the study area, where moderate to the large landslide is associated with Argillic alteration, meanwhile small to moderate landslide is associated with propylitic alteration.
\end{abstract}

\section{Introduction}

Landslide is one of the most frequent hazards that happened in Indonesia. The geologic conditions of Indonesia have resulted in several conditions that served opportunity for the landslide development. Ring of fire chain that lies from the north of Sumatra to Banda Islands and North Sulawesi produced volcanic rocks as well as producing hydrothermal activity. Hydrothermal fluid activity, in negative ways, could be altered and weaken the rocks. On the other hand, the weakened rock increased the landslide susceptibility. One of the areas characterized by its frequent landslide events can be found in Kulon Progo Mountains. The study area is administratively located in Durensari Area, Bagelen Subdistrict, Purworejo District, Central Java, Indonesia. The study area is characterized by its mountainous terrain, constructed by extrusive volcanic rocks and intrusive igneous rocks from the tertiary volcanic activity of Mount Ijo, one of three volcanoes identified in Kulon Progo Mountains [1,2]. The study area (Figure 1) is located about $40 \mathrm{~km}$ from Yogyakarta City.

This research is conducted to connect the hydrothermal alteration and landslide occurrence in the study area. This study is also suggested as a preliminary method to reduce the landslide damage in the future by supporting the decision for spatial planning in the study area.

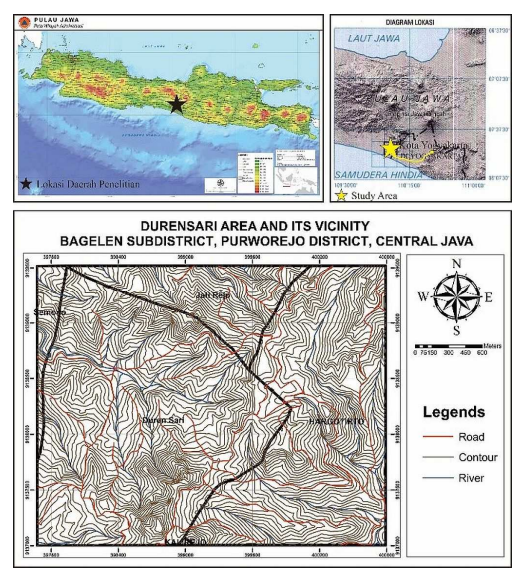

Fig. 1. Study area location (1) study area on the central-south of Java; (2) study area on the border of Central Java and Yogyakarta and (3) three administrative villages of the study area.

\section{Regional geology}

Physiographically, based on Barianto et al. (2009) [2], the study area is located in Kulon Progo Mountains, which means, the study area is characterized by volcanic landform from eruption product of Mount Ijo. Stratigraphically, the study area is constructed by several formations/ rock units. Based on Rahardjo et al. (1995) [1] and Harjanto (2011) [3], order of formation/ rock units (oldest to youngest) are named by 1) Nanggulan Formation, which consists of siliciclastic sandstone,

\footnotetext{
Corresponding author: adtitisari@gmail.com
} 
siltstone, and claystone, 2) Old Andesite Formation which consists of several volcanic rocks of Breccia, Tuff, and Lapilli Tuff, 3) Andesite Intrusion, which constructs almost all of study area, with the variety of Hypersthene, Hornblende, Augite, and Trachyandesite, 4) Dacite Intrusion, which intruded Andesite, 5) Jonggrangan Formation, which consists of calcareous siltstone/ claystone or sandstone, 6) Sentolo Formation, which consist of limestone variety, and 7) Quaternary Alluvium.

The tertiary hydrothermal activity also produced altered rocks in the Kulon Progo Mountain. The hydrothermal alteration zones have been identified, named by phyllic alteration, argillic alteration, and propylitic alteration [4]. The research activity about hydrothermal alteration also has been done by Anshori and Hastria (2013) [5] in Kokap area that located near the study area shown that there are two temperature zones of alteration, $175-230{ }^{\circ} \mathrm{C}$ and $280-340{ }^{\circ} \mathrm{C}$. This alteration conditions later became one of the factors that affect and triggers the landslide occurrences, as commonly it occurs at altered rocks instead of unaltered ones.

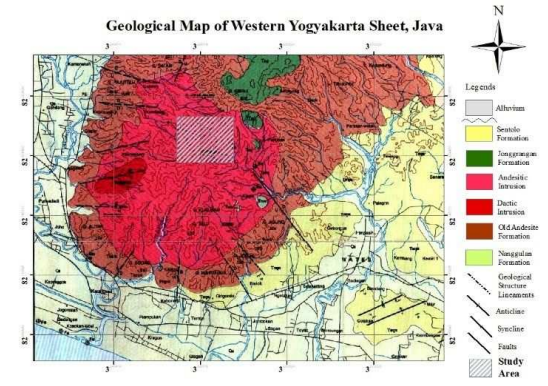

Fig. 2. Geological map of the study area [1].

\section{Methods}

Clay minerals are categorized in phyllosilicate mineral. The clay mineral group are formed at low and high temperature [6]. Clay minerals, as the product of the hydrothermal alteration process, have been studied back in previous years. The geological conditions of lithology and its diagenesis products, geologic structure, slope degree, relative relief, land use, and hydrological conditions of the slope are factors that control landslide occurrence in the mountainous terrain [7].

In several cases, the presence of hydrothermal activity is often related to the landslide event. Previously research done by Pola et al. (2012) [8], Frolova et al. (2015) [9], Julia et al. (2014) [10], Ludovic et al. (2004) [11] and Winarti et al. (2016) [12] have resulted in that clay minerals in the hydrothermally altered area could affects the landslide susceptibility. Ludovic et al. (2004) [11] conclude that clay minerals influenced the rocks by increasing it pore pressure of water by increased porosity and low permeability. Pola et al. (2012) [8] conclude that hydrothermal alteration clay minerals could lower the density of rocks as well as increasing its porosity, which is controlled by its degree of alteration. Frolova et al. (2014) [9] stated that the low-temperature hydrothermal alteration would weaken the rocks as it commonly produced clay minerals that could increase the porosity and moisture, but lower the permeability, density, and strength of the rocks. Winarti et al. (2016) [12] conclude that clay minerals could break the interlayer sheet bonding of the rocks, especially for Smectite group mineral for its swelling properties.

In this study, field observation and X-ray diffraction (XRD) are used as a method to identify the landslide occurrence point and identifying the clay minerals in the study area.

\section{Results and discussions}

\subsection{Field observation}

Field observation is done by field mapping of landslide occurrences, as well as choosing rock sample stations. Area of $2.5 \times 2.5$ kilometers has been mapped and resulted in \pm 25 landslide occurrence locations. Later, the resulted map is displayed at a scale of 1:15000 as shown in Figure 3. The study area is commonly composed by andesite intrusion, where andesite variety rock are found in the study area showing grayish black, gray, or whitish black variety, while megascopically, rock textures observed showing fine aphanitic and porphyroaphanitic variety.

As the product of alteration process, several rocks showing different characteristics, such as the color, porosity, permeability, weight (density), and moisture. Unaltered Andesite shows grayish black, gray, or whitish black color, meanwhile altered Andesite shows the wider variety of color such as greenish gray, brownish gray, dark brown, and more. In porosity and permeability, unaltered rock shows low primary porosity and permeability, meanwhile altered rock showing increased primary porosity as alteration intensity degree increased, but low primary permeability. In weight and moisture, unaltered Andesite shows denser compared to altered rocks, which are lighter, but have higher moisture than unaltered ones. Field observation has resulted in about 30 location of past and present landslide event that related to clay mineral presence in the study area.

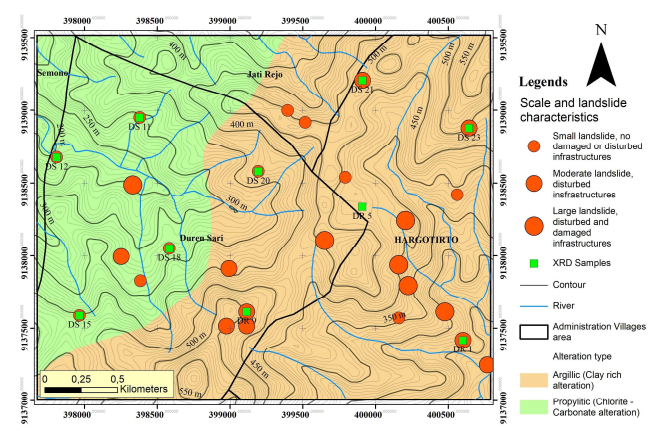

Fig. 3. Landslide points and XRD sample stations of the study area. 


\subsection{Laboratory observation}

$\mathrm{XRD}$ method is done as a laboratory observation method. Ten rocks samples are observed, in the condition of least to heavily altered rocks. The results show that several hydrothermal alteration clay minerals have been identified, such as smectite, chlorite, illite, kaolinite and mix clay minerals. Clay minerals identified in this study are summarized in Table 1.

Table 1. Tabulation of clay minerals identified.

\begin{tabular}{|c|l|l|}
\hline No & Sample/Station & \multicolumn{1}{|c|}{ Clay minerals } \\
\hline 1 & DR 1/ St 2 & Kaolinite \& illite \\
\hline 2 & DR 5/ St 10 & $\begin{array}{l}\text { Mix llite-smectite, illite \& } \\
\text { kaolinite }\end{array}$ \\
\hline 3 & DR 9/ St 16 & Smectite, kaolinite, \& illite \\
\hline 4 & DS 11/ St 18 & $\begin{array}{l}\text { Chlorite, smectite, Illite, \& } \\
\text { kaolinite }\end{array}$ \\
\hline 5 & DS 12/ St 19 & $\begin{array}{l}\text { Chlorite, smectite, illite, \& } \\
\text { kaolinite }\end{array}$ \\
\hline 6 & DS 15/ St 22 & $\begin{array}{l}\text { Chlorite, smectite, illite \& } \\
\text { kaolinite }\end{array}$ \\
\hline 7 & DS 18/ St 25 & $\begin{array}{l}\text { Chlorite, smectite, kaolinite, \& } \\
\text { illite }\end{array}$ \\
\hline 8 & DS 20/ St 27 & Smectite, kaolinite, \& illite \\
\hline 9 & DS 21/ St 28 & $\begin{array}{l}\text { Smectite, mix kaolinite- } \\
\text { smectite, kaolinite, illite }\end{array}$ \\
\hline 10 & DS 23/ St 30 & $\begin{array}{l}\text { Mix kaolinite-smectite, } \\
\text { kaolinite \& illite }\end{array}$ \\
\hline
\end{tabular}

*bold- written minerals are dominant secondary minerals

\subsection{Discussions}

In the study area and its vicinity, where hydrothermal alteration appears due to past hydrothermal activity, the hydrothermal alteration of rocks is expected as the main factor that affecting the landslide susceptibility. Clay minerals identification has been done based on their standard behavior, which has been summarized by Chen (1977) [13] and JCPDS (N.D) [14]. Clay minerals identified are listed in Table 2, where the presence of those minerals and its assemblages can be grouped into two type of alteration type, the argillic and propylitic. The presence of argillic alteration is expected to affect the landslide susceptibility more than propylitic, as can be found in the field that the presence landslide points are associated dominantly with argillic alteration type, and few landslide points are associated with propylitic type. In its relation to a landslide, the clay minerals, based on (Browne, 1984) [15], is commonly present as replacement of primary minerals such as plagioclase and volcanic glass. Replacement process of primary minerals by secondary minerals, especially clays could weaken the rocks and increasing susceptibility for a landslide. The difference in landslide sensitivity then also affected by the alteration type, especially caused by its main clay minerals in each type of alteration.

Argillic alteration is characterized by the presence of smectite, kaolinite, and illite as main hydrothermal alteration minerals [16]. Argillic alteration area is also characterized by the presence of many landslide points (about 18 landslide points), which have moderate to large landslide characters. The clay minerals, as mentioned before are replacing the primary minerals of rock and weaken the rock. On the other hand, based on previous research, Smectite mineral group as one of the main clay minerals found in this study also known by its swelling or expanding properties. This expanding property later is expected as the minerals that have strong influence to landslide susceptibility in argillic alteration area because it can break rock bonds [12]. Smectite group minerals are found in all locations in the study area. This mineral group is formed at low temperature $\left(<200^{\circ} \mathrm{C}\right)$ in neutral $\mathrm{pH}$ fluid [17].

Propylitic alteration is mainly characterized by the presence of chlorite minerals and also smectite, kaolinite, and illite as the accessory minerals [16]. Propylitic alteration zone is found in the West to Northwest side. Propilytic alteration is characterized by its small to moderate landslide points (about 7 landslide points). Based on Reyes (2000) [17], chlorite is formed in wide temperature extend $\left(>120{ }^{\circ} \mathrm{C}\right)$. Replacement process of primary rock constituent by clay minerals are expected to weaken the rocks and affect the landslide. The presence of landslide in propylitic alteration area are also expected occur because the presence of smectite expanding minerals, but in smaller percentage, because smectite minerals only found as accessory minerals in propylitic alteration area.

Based on the discussion above, can be concluded that the presence of clay minerals could affect the landslide susceptibility in the study area. The replacement process of primary constituent minerals of rock is expected affect the landslide susceptibility as well as the presence of smectite minerals also expected as the minerals that enhancing landslide susceptibility and occurrences by its swelling/ expanding properties.

\section{Conclusion and suggestion}

\subsection{Conclusion}

From the study above, can be concluded several conclusions to answer the research goals, there are:

1. Clay minerals as products of hydrothermal alteration process that identified in this study are smectite group mineral (montmorillonite), chlorite, illite, caolinite and mix clay minerals of kaolinite-smectite and illite-smectite. This mineral later can be divided into two alteration type, the argillic (smectite, illite, caolinite) and propylitic (chlorite, smectite, illite, caolinite) alteration.

2. Field and laboratory observation showed there are relations between hydrothermal alteration clay minerals and landslide occurrences. The argillic alteration has stronger relations to landslide susceptibility as the moderate to large landslide are mainly found in argillic alteration, meanwhile the propylitic alteration also show relation to landslide susceptibility, but weaker than argillic alteration, where small to moderate landslide are found in propylitic alteration. 


\subsection{Suggestion}

In the study area, much of human activity is concentrated in the area where clay minerals are formed. Due to that facts, several actions are needed to minimize the landslide occurrences by building the construction that could prevent the landslide, such as prioritize irrigation, or "talud" construction in argillic alteration area than propylitic alteration area.

The authors would like to say thank you to Geological Engineering Department and Faculty of Engineering, Universitas Gadjah Mada for research funding support.

\section{References}

1. W. Rahardjo, Sukandarrumidi, H. M. D. Rosidi, Geological Map of Yogyakarta Sheet, Jawa (1995)

2. D. H. Barianto, A. Harijoko, K. Watanabe. Eart. Sci. Int. Conf. (to be published)

3. A. Harjanto, Jur. Ilm. MTG. 4, 1 (2011)

4. A. Harjanto, Jik. TekMin. 23, 3 (2010)

5. C. Ansori, D. Hastria, Sum. Daya. Geol. Bull, 8, 7586, 2 (2013)

6. B. Velde, A. Meunier. The Origin of Clay Minerals in Soils and Weathered Rocks (2008)

7. R. Anbalagan, Eng. Geol. J. 32, 269-277 (1992)

8. A. Pola, G. Crosta, N. Fusi, V. Barberini, G. Norini, Tectonoph. Jour. 566-567, 67-86 (2012)

9. J. V. Frolova, I. P. Gvozdeva, N. P. Kuznetsov, Proceeding of World Geothermal Congress, Melbourne (2015)

10. F. Julia, L. Vladimir, R. Sergey, Z. David, Eng. Geol. Jour. 183, 80-95 (2014)

11. W.A.S. Ludovic, R. Kitagawa., T. M. Felix, E. G. Emmanuel, N. Daniel, Clay. Sci. Jour. 12, 293-304 (2004)

12. D. Winarti, D. Karnawati, H. C. Hardiyatmo, Srijono. Jour. Of Appl. Geol. 1, 19-28 (2016)

13. JCPDS, JCPDS XRD Database (N.D.)

14. P. Y. Chen, Table of key lines in X-ray powder diffraction patterns of minerals in clays and associated rocks (1977)

15. P. R. L. Browne, Lectures on geothermal geology and petrology, UNU GTP Lecture notes (1984)

16. Thompson, A. J. B. and Thompson, J. F. H. Atlas of alteration. A field and petrographic guide to. Hydrothermal alteration minerals (1996)

17. A. G. Reyes, Petrology and mineral alteration in hydrothermal systems: From diagenesis to volcanic catastrophes, UNU GTP Lecture notes (2000) 


\section{Appendixes}

\section{Appendix 1. Field documentations}

Landslide occurrence in study area: Damaged infrastructures of village road and resident's houses (left) and close up appearance of altered rocks that enhanced the landslide occurrence, note the black metallic, brown, and white color as the hydrothermal alteration minerals (right).
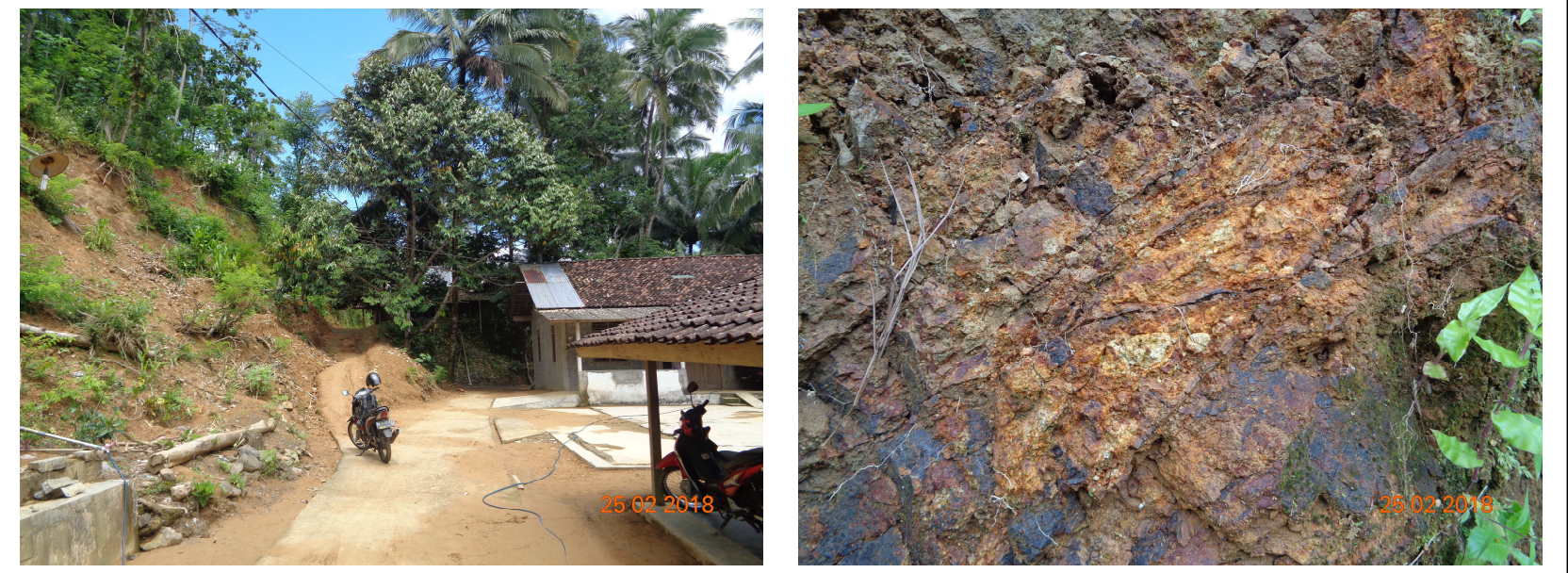

\section{Appendix 2. XRD Diffractograms}

XRD Diffractograms of clay mineral representatives, $1^{\text {st }}$ ) DR 1 sample showing illite and kaolinite mineral, $2^{\text {nd }}$ ) DR 5 sample showing mix illite-smectite, Illite, and kaolinite mineral, $3^{\text {rd }}$ ) DS 15 sample showing smectite, kaolinite, chlorite and illite mineral, and $4^{\text {th }}$ ) DS 21 sample showing smectite, Kaolinite-smectite, illite, and kaolinite.
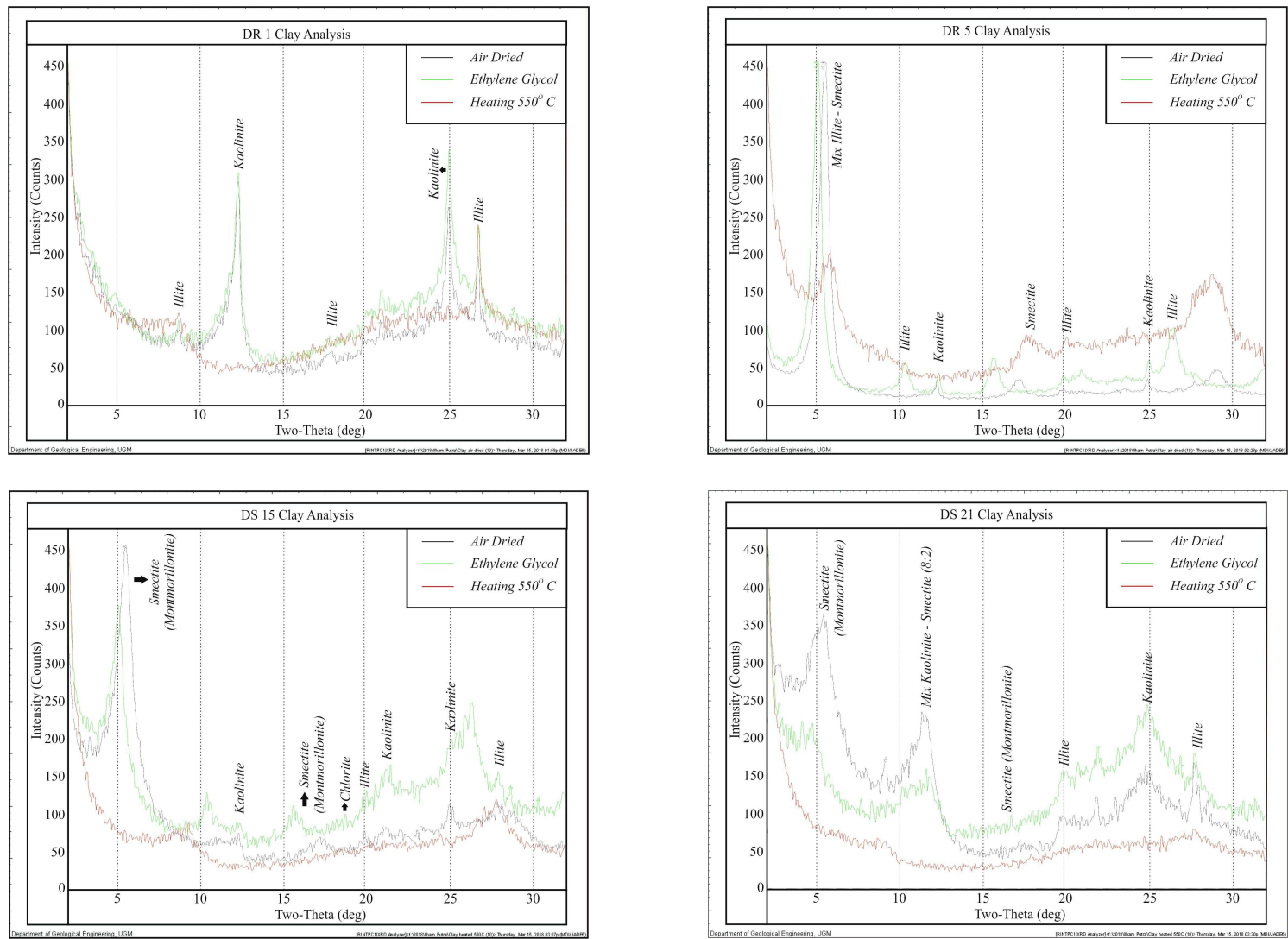